Agrovoc descriptors: plant nutrition; selenium; antioxidants; environmental factors; resistance to injurious factors; oxidation; photooxidation; stress; senescence; water metabolism

Agris category code: F61, F62, F04

COBISS code 1.02

\title{
Selenium and plants
}

\author{
Mateja GERM ${ }^{1}$, Vekoslava STIBILJ ${ }^{2}$
}

Received: May 3, 2007; accepted: June 20, 2007.

Prispelo 3. maja 2007; sprejeto 20. junija 2007.

\begin{abstract}
Selenium is of metabolic importance in cyanobacteria and in some plants, being involved in their antioxidative processes. Selenium is widely distributed on the Earth's surface and available for plants in at least small traces. Cultivation of plants enriched with selenium could be an effective way of producing selenium rich foodstuffs and thereby increase health benefits. The essentiality of selenium to higher plants is still under debate. Selenium can increase the tolerance of plants to UV-induced oxidative stress, delay senescence, and promote the growth of ageing seedlings. Recently it has been shown that selenium has the ability to regulate the water status of plants under conditions of drought. The distribution and speciation of selenium in plants and the effect of selenium alone and in combination with some other environmental parameters is discussed.
\end{abstract}

Key words: selenium, plants

\section{IZVLEČEK}

\section{SELEN V RASTLINAH}

Selen ima pomembno vlogo pri antioksidativnih procesih cianobakterij in nekaterih rastlin. Selen je široko razžirjen po zemeljski obli in na razpolago rastlinam vsaj v majhnih količinah. Gojenje rastlin, obogatenih s selenom, je učinkovit način dodajanja selena ljudem in izboljšanju zdravja. $V$ znanstvenem svetu poteka debata, ali je selen potreben za rastline. Obstajajo pa dokazi, da selen pri rastlinah pospešuje antioksidacijsko aktivnost, zavira procese, povezane s staranjem in omili stres zaradi visoke svetlobe in tudi suše. $V$ članku je opisana sposobnost rastlin za akumulacijo selena in vpliv selena v kombinaciji za nekaterimi drugimi okoljskimi dejavniki na rastline.

Ključni besedi: selen, rastline

\section{INTRODUCTION}

Selenium is a trace element that can function as an essential nutrient for humans and animals or as an environmental toxicant; the boundary between the two is narrow and

1 National Institute of Biology, Večna pot 111, Ljubljana, SI-1000. Dr., univ. dipl. biol., Email:mateja.germ@nib.si

2 Jožef Stefan Institute, Jamova 39, Ljubljana, SI-1000. Dr., univ. dipl. kem. 
depends on its chemical form, concentration, and other environmentally regulating variables (Fan et al., 2002; Shardendu et al., 2003). It is an important microelement, exists in small amounts in microorganisms, plants, animals and humans. Although selenium is an essential trace nutrient important to humans and most other animals as an antioxidant, toxicity occurs at high concentrations due to replacement of sulphur with selenium in amino acids resulting in incorrect folding of the protein and consequently nonfunctional proteins and enzymes.

\section{BENEFICIARY EFFECT OF SELENIUM TO HUMANS}

Some regions like Slovenia, suffer from a relative deficiency of selenium (Pirc and Šajn, 1997). Cultivation of plants enriched with selenium could be an effective way of producing selenium rich foodstuffs and thereby increase health benefits (Ip and Lisk, 1994; Finley et al., 2001; Lyons et al., 2005). Selenium has an important role in the prevention of atherosclerosis, specific cancers, arthritis, and altered immunological functions. The beneficial effects of selenium are dependent on the chemical form. Selenomethionine (SeMet) is known to be the most readily assimilated form of selenium (Patrick, 2004). Supplementation of human diet with selenium yeast, containing SeMet as the main chemical form, significantly reduced the occurrence of prostate cancer (Duffield-Lillico et al., 2003).

\section{EFFECT OF SELENIUM ON PLANTS}

The essentiality of selenium to higher plants is still under debate (Terry et al., 2000). Selenium can increase the tolerance of plants to UV-induced oxidative stress, delay senescence, and promote the growth of ageing seedlings (Xue et al., 2001; Pennanen et al., 2002). Recently it has been shown that selenium has the ability to regulate the water status of plants under conditions of drought (Kuznetsov et al., 2003). Hartikainen et al. (2000) reported about growth promoting effect of selenium in ryegrass. Senescence stress is partly counteracted with enhanced antioxidation which is associated with an increase glutathione peroxidase (GSH-Px) activity. Although some studies have evaluated the effect of hardness, temperature, $\mathrm{pH}$ and other parameters on selenium toxicity, sulphate has perhaps been most widely studied in relation to selenium uptake and toxicity in aquatic and terrestrial organisms (Sappington, 2002). Selenium and sulphur are nutrients with very similar chemical properties and their uptake and assimilation proceed through common pathways (Eapen in D'Souza, 2005).

\section{ABILITY OF PLANTS TO ACCUMULATE SE}

Se has not been classified as an essential element for plants, although its role has been considered to be beneficial in plants capable of accumulating large amounts of the element (Terry et al., 2000). Uptake and accumulation of selenium by plants is determined by the chemical form and concentration, soil factors such as $\mathrm{pH}$, salinity and $\mathrm{CaCO}_{3}$ content, the identity and concentration of competing ions, and the ability of the plant to absorb and metabolize selenium (Kabata Pendias, 2001). Actively 
growing tissues usually contain the largest amounts of selenium (Kahakachchi et al., 2004). Plants usually accumulate more selenium in shoot and leaf than in root tissues (Zayed et al., 1998).

\section{RESEARCH IN SLOVENIA}

\subsection{Methodology}

On Jožef Stefan Institute, Biotechnical faculty and National Institute of Biology, the determination of selenium in plants and their species, and on the other hand the effect of selenium on plants are studied (Smrkolj and Stibilj, 2004; Breznik et al., 2005; Germ et al., 2005a,b; Smrkolj et al., 2005; Smrkolj et al., 2006a). Selenium is applied either as foliarly spraying, either by soaking the seeds in the solution of selenium. Model plants are cultivars of Phaseolus vulgaris, Eruca sativa, Pisum sativum, Glicine max, Fagopyrum eculentum, F. tataricum, Hypericum perforatum, Cucurbita pepo,...). Experiments are conducted in glass houses as well as in semi-controlled conditions and outdoors. The effect of selenium on plants is in certain cases combined with other factors, like UV-B radiation (Fagopyrum esculentum, F. tataricum, Cucurbita pepo) and drought (Solanum tuberosum).

\subsection{Distribution of selenium and its species in plants}

It was shown, that pea was good accumulators of selenium. The selenium content of pea seeds obtained from the untreated (UT group), once (OT) and twice (TT) foliarly treated plants was determined. The selenium content of pea seeds obtained from the untreated, once and twice foliarly treated plants was, in each case, directly proportional to the number of spraying applications. Seeds are usually a moderate source of selenium, but several studies dealing with cereal and legume seeds showed, that they are able to accumulate high amounts of selenium (Stadlober et al., 2001; Smrkolj et al., 2005; Smrkolj et al., 2006a). Higher selenium contents were found in leaves than in stems of plants grown from both OT and TT seeds, and these contents were, as for the seeds, directly proportional to the number of original foliar treatments (Smrkolj et al., 2006a). Selenomethionine was the only selenium compound found in supernatants by anion and cation exchange chromatography, comprising 49 and $67 \%$ of the total selenium content in the OT and TT groups, respectively (Smrkolj et al., 2006a). The results of the study show that selenium enriched pea seeds are potential source of dietary selenium, on account of their ability to accumulate Se, and that this selenium is present mainly as SeMet, known to be favourable for human consumption (Smrkolj et al., 2006a).

Common (Fagopyrum esculentum) and tartary (Fagopyrum tataricum) buckwheat was treated by spraying the leaves with a water solution containing in the form of sodium selenate in the flowering period. The selenium content in all parts of plant was found to be less than $200 \mathrm{ng} \mathrm{g}^{-1}$ in non-treated and in the range $2700-4650 \mathrm{ng} \mathrm{g}^{-1}$ in selenium treated buckwheat. Exposure to UV-B radiation lead to higher selenium accumulation in flowers of both selenium enriched cultivars. In flowers and leaves, on average $11 \%$ of the selenium content was soluble and in the form of $\mathrm{Se}(\mathrm{VI})$, representing between $0.6 \%$ (flowers) and 3\% (leaves) of the selenium content. In 
seeds $93 \%$ of the selenium content was found in the extracts and the main selenium species was SeMet with $93 \pm 5 \%$ relative to the selenium content (Smrkolj et al., 2005).

Determination of selenium compounds was performed in chicory (Cichorium intybus) leaves from plants which were cultivated aeroponically with elevated concentrations of $\mathrm{Na}_{2} \mathrm{SeO}_{4}$ for different periods. Selenium accumulated efficiently in chicory leaves; up to $480 \mu \mathrm{g} / \mathrm{g}$ after 41 days of exposure, mostly $(64 \%)$ as $\mathrm{Se}^{\mathrm{VI}}$, i.e. in the form of selenium added. Beside inorganic Se, they also found SeMet (4.2-8.4\%) and SeMeSeCys ( $<\mathrm{DL}-0.7 \%)$ (Mazej et al., 2006).

Data of content of selenium and its species in different plants are shown in Table 1.

Table 1. Literature data of content of selenium and its species in leaves of different plants.

\begin{tabular}{|c|c|c|c|c|}
\hline Plant & Se addition & $\begin{array}{c}\text { Total Se in } \\
\text { leaves } \\
\text { ( } \mu \mathrm{g} / \mathrm{g} \text { dry } \\
\text { weight) }\end{array}$ & SeMeSeCys $(\%)^{\mathrm{a}}$ & Literature \\
\hline $\begin{array}{c}\text { Chicorv (leaves) } \\
\text { (Cichorium intybus L.) }\end{array}$ & \multirow{4}{*}{$\begin{array}{c}\mathrm{Na}_{2} \mathrm{SeO}_{4} \\
7 \mathrm{mg} / \mathrm{L} \\
41 \text { days } \\
\text { aeroponically }\end{array}$} & $167-480$ & $0.5-1.7$ & \multirow{4}{*}{ Mazej et al., 2007} \\
\hline $\begin{array}{l}\text { Lamb's lettuce (leaves) } \\
\text { (Valerianella locusta L.) }\end{array}$ & & 455 & 3.0 & \\
\hline $\begin{array}{c}\text { Dandelion (leaves) } \\
\text { (Taraxacum officinale } \\
\text { Waggers) }\end{array}$ & & 49 & 2.0 & \\
\hline $\begin{array}{c}\text { Parsley (leaves) } \\
\text { (Petroselinum crispum } \\
\text { Mill.) }\end{array}$ & & 290 & 4.4 & \\
\hline $\begin{array}{c}\text { Bean (seeds) } \\
\text { (Phaseolus vulgaris L.) }\end{array}$ & $\begin{array}{l}\mathrm{Na}_{2} \mathrm{SeO}_{4} \\
10 \mathrm{mg} / \mathrm{L} \\
10 \text { days }\end{array}$ & 2 & 30 & Smrkolj, 2006b \\
\hline
\end{tabular}

${ }^{a}$ - \% SeMeSeCys relative to total Se in sample

\subsection{The response of plants to selenium and with combination with other environmental parameters}

Physiological parameters were measured in control plants and in plants obtained from selenium treated seeds in Eruca sativa and in foliarly treated Fagopyrum esculentum and F. tataricum. The potential and effective quantum yields of photosystem II were unaffected by selenium in Eruca sativa, Fagopyrum esculentum and F. tataricum (Germ and Osvald, 2005; Breznik et al., 2005a). The respiratory potential of Eruca sativa, measured by electron transport system (ETS) activity, significantly increased in plants, grown from selenium treated seeds (Germ and Osvald, 2005). The similar results were given in the study on young plants of $P$. sativum; ETS activity was highest in young pea leaves with the highest selenium content (Smrkolj et al., 2006a). Selenium induced higher respiratory potential in the leaves of foliarly treated selenium in $S$. tuberosum cv. Desiree, (unpublished data). Higher ETS activity reflected increased GSH-Px activity in mitochondria (Smrkolj et al., 2006a). It was 
evidenced (Xue and Hartikainen, 2000; Hartikainen et al., 2000; Xue et al., 2001) that selenium exposure increased GSH-Px activity in ryegrass and lettuce. However, selenium did not affect respiratory potential in F. esculentum and F. tataricum (Breznik et al., 2005a), foliarly treated with selenium.

\subsection{The combined effect of selenium with other environmental parameters}

The addition of selenium mitigated the negative effect of UV-B radiation on effective quantum yield of PSII in both buckwheat species. The protective effect of selenium is important because it improves light harvesting and through this the availability of energy for plants (Breznik et al., 2005a). An ameliorative effect of Se, with regard to mass of the tubers, was observed in drought exposed in S. tuberosum cv. Desiree (unpublished data). Recently it has been shown that selenium has the ability to regulate the water status of plants under conditions of drought; selenium causes enhanced water retention in wheat tissue (Kuznetsov et al., 2003). The influence of ambient and filtered solar UV-B radiation and of selenium treatment was determined in pumpkins, Cucurbita pepo L. It was shown, that selenium increased yield under ambient radiation conditions (Germ et al., 2005).

Enhanced UV-B radiation negatively affected the aboveground biomass and number of seeds in foliarly treated $F$. esculentum with selenium. The interactions between selenium and UV-B radiation to aboveground biomass, number of nodes and number of seeds were obtained (Breznik et al., 2005b)

The aim of our future work is the continuation research regarding of the ability of plants to accumulate selenium, determination of selenium species in plants, and the effect of selenium on physiological and morphological characteristics of plants. We will study the combined effects of selenium on plants with other environmental parameters. We would like to assess the threshold of selenium beneficiary effects and toxicity. Additionally, the way of application of selenium to plants, which is the most safe for the nature will be assessed. And also, to determine which cultivated plants have ability to assimilate selenium to be the most suitable for the human nutrition.

\section{ACKNOWLEDGEMENT}

This research is a part of the projects financed by the Slovenian Research Agency (ARRS), Ljubljana: "Physiological indicators of stress in cultivated plants" (J4-64280105-04/4.03), "The influence of UV-B radiation to antioxidant content and distribution in cultivated plants" (J7-9805-0106-06), and Functional Food Project (J49673-0481-06).

\section{REFERENCES}

Breznik B., Germ M., Gaberščik A., Kreft I. 2005a. Combined effects of elevated UV-B radiation and the addition of selenium on common and tartary buckwheat. Photosynthetica, 43: 583-589. 
Breznik B., Germ M., Gaberščik A., Germ M., Kreft I. 2005b. The combined effects of enhanced UV-B radiation and selenium on common buckwheat (Fagopyrum esculentum Moench) habitus. Fagopyrum, 22: 83-87.

Duffield-Lillico A.J., Dalkin B.L., Reid M.E., Turnbull B.W., Slate E.H., Jacobs E.T., Marshall J.R., Clark L.C. 2003. Selenium supplementation, baseline plasma selenium status and incidence of prostate cancer: an analysis of the complete treatment period of the Nutritional Prevention of Cancer Trial. BJU International 91, 608-612.

Eapen S., D'Souza S.F. 2005. Prospects of genetic engineering of plants for phytoremediation of toxic metals. Biotechnol. Adv., 23: 97-114.

Fan R.W.M., The S.J., Hinton D.E., Higashi R.M. 2002. Selenium biotransformations into proteinaceous forms by foodweb organisms of selenium-laden drainage waters in California. Aquatic Toxicol., 57: 65-84.

Finley J.W., Ip C., Lisk D.J., Davis C.D., Hintze K.J., Whanger P.D. 2001. Cancer-protective properties of high-selenium broccoli. J. Agric. Food Chem., 49: 2679-2683.

Germ M., Osvald J. 2005. Selenium treatment affected respiratory potential in Eruca sativa Acta agric. Slov., 85(2): 329-335.

Germ M., Kreft I., Osvald J. 2005. Influence of UV-B exclusion and selenium treatment on photochemical efficiency of photosystem II, yield and respiratory potential in pumpkins (Cucurbita pepo L.). Plant Physiol. Biochem., 43: 445-448.

Hartikainen H., Xue T., Piironen V. 2000. Selenium as an antioxidant and pro-oxidant in ryegrass. Plant Soil, 225: 193-200.

Ip C.P., Lisk D.J. 1994. Enrichment of selenium in allium vegetables for cancer prevention. Carcinogenesis, 15: 1881-1885.

Kabata Pendias A. 2001. Trace Elements in Soils and Plants, $3^{\text {rd }}$ ed., Boca Raton, FL: CRC Press, 241-252.

Kahakachchi C., Boakye H.T., Uden P.C., Tyson J.F. 2004. Chromatographic speciation of anionic and neutral selenium compounds in Se-accumulating Brassica juncea (Indian mustard) and in selenized yeast. J. Chromatogr. A, 1054: 303-312.

Kuznetsov V.V., Kholodova V.P., Kuznetsov VI.V., Yagodin B.A. 2003. Selenium regulates the water status of plants exposed to drought. Dokl. Biol. Sci., 390: 266-268.

Lyons G., Ortiz-Monasterio I., Stangoulis J., Graham R. 2005. Selenium concentration in wheat grain: Is there sufficient genotypic variation to use in breeding? Plant Soil, 269: 369-380.

Mazej D., Falnoga I., Veber M., Stibilj V. 2006. Determination of selenium species in plant leaves by HPLC-UV-HG-AFS. Talanta, 68: 558-568.

Mazej D., Osvald J., Stibilj V. 2007. Selenium species in leaves of chicory, dandelion, lamb's lettuce and parsley. Food. Chem, in press.

Patrick L. 2004. Selenium biochemistry and cancer: a review of the literature. Altern. Med. Rev., 9: 239-258.

Pennanen A., Xue T., Hartikainen H. 2002. Protective role of selenium in plant subjected to severe UV irridiation stress. J. Appl. Bot., 76: 66-76.

Pirc S., Šajn R. 1997. The influence of geochemistry in determination of chemical loading of environment. Ljubljana, Slovenian Ecological Society, 165-185 (in Slovenian).

Sappington K.G. 2002. Development of aquatic life criteria for selenium: a regulatory perspective on critical issues and research needs. US Environmental Protection 
Agency, Office of Research and Development, National Center for Environmental Assessment (8623D). Aquatic Toxicol., 57: 101-113.

Shardendu S.N., Boulyga S.F., Stengel E. 2003. Phytoremediation of selenium by two helophyte species in subsurface flow constructed wetland. Chemosphere, 50(8): 967973.

Smrkolj P., Stibilj V. 2004. Determination of selenium in vegetables by hydride generation atomic fluorescence spectrometry. Anal. Chim. Acta, 512: 11-17.

Smrkolj P., Stibilj V., Kreft I., Germ M. 2005. Selenium species in buckwheat cultivated with foliar addition of $\mathrm{Se}(\mathrm{VI})$ and various levels of UV-B radiation. Food Chem., 96: 675681.

Smrkolj P., Germ M., Kreft I., Stibilj V. 2006a. Respiratory potential and Se compounds in pea (Pisum sativum L.) plants grown from Se enriched seeds. J. Exp. Bot., 57: 35953600 .

Smrkolj P., Osvald M., Osvald J., Stibilj V. 2006b. Selenium uptake and species distribution in selenium-enriched bean (Phasolus vulgaris L.) seeds obtained by two different cultivations. Europ. Food Res. Technol., in press.

Stadlober M., Sager M., Irgolic K.J. 2001. Effects of selenate supplemented fertilisation on the selenium level of cereals-identification and quantification of selenium compounds by HPLC-ICP-MS. Food Chem., 73: 357-366.

Terry N., Zayed A., De Souza M.P., Tarun A.S. 2000. Selenium in higher plants. Annu. Rev. Plant Physiol. Plant Mol. Biol., 51: 401-432.

Zayed A., Lytle C.M., Terry N. 1998. Accumulation and volatilization of different chemical species of selenium by plants. Planta, 206(2): 284-292.

Xue T.L., Hartikainen H. 2000. Association of antioxidative enzymes with the synergistic effect of selenium and UV irradiation in enhancing plant growth. Agric. Food Sci. Finland, 9(2): 177-186.

Xue T.L., Hartikainen H., Piironen V. 2001. Antioxidative and growth-promoting effects of selenium on senescing lettuce. Plant Soil, 237: 55-61. 